\title{
Urban activity in the transformation of a military fortress into a county town in the Czech Republic
}

\author{
L. Teslíková Hurdálková \& D. Kutá \\ Department of Urban Engineering, Faculty of Civil Engineering, \\ VSB-TU Ostrava, Czech Republic
}

\begin{abstract}
The Zoning Plan of Hradec Kralove creates conditions for developing the chartered city so as to strengthen its natural status as the administrative centre of Hradec Králové and the Czech Republic and one of the core areas of the Hradec Králové - Pardubice agglomeration. Conversion of the provincial, heavily fortified city into its current form, a stronger regional city, ran from the second half of the 19th century. Several key milestones in the development of the city were due to the conscious approach of the city leaders. The first important impulse of the urban development was 20 June 1858 when they cancelled fortress headquarters, including the ban on the construction of the fortress perimeter. This paper deals precisely with urban activities in the transformation of a military fortress into the county town, as well as with how architectural Hradec Kralove focus on the functional use influenced contemporary urban planning of the city. Keywords: fortress, Redevelopment Law, protective zone, regulation plan, zoning plan, built-up areas, redevelopment areas.
\end{abstract}

\section{Introduction}

The main initiator of strategic planning was JUDr. František Ulrich, a long-time mayor (1895-1929) of the City of Hradec Králové who had merits in the modern redevelopment and growth of the city, which was the reason for the Hradec nickname the "Country Saloon". Architect Josef Gočár also significantly affected the city development. Gočár's work belongs to masterpieces of the Czech modern architecture and his share in the urban concept of Hradec Králové is major. Since the beginning of the 1920 s, he gradually generated the city zoning plan, created 
the riverside regulation plan, development in the Labe river basin, school blocks (J. K. Tyl's Grammar School) and city centre (currently the Ulrichovo náměstí square). The development plans also included the outer traffic circuit with radial roads leading to the city centre where residential districts alternate with green areas.

The middle of the 19th century did not indicate that Hradec Králové would be a modern metropolis of East Bohemia several years later. This capital situated at the junction of the Labe and Orlice rivers, fortified by huge brick walls with its core without possibility of further development, was surrounded by deserted meadows, which was the reason for why this fort could not be omitted. Despite the fortification limiting factors, the city remained to be the centre of authorities, trades, crafts, schools and other institutions including a strong military post.

The year 1850 became an important milestone in the city history when Hradec Králové was declared an independent city. At that time, the suburban towns separated and became politically independent despite indignation of the original citizens. Original size of the urban formation was $50 \mathrm{~km}^{2}$ with 15 city districts with almost 1,000 populated houses. The separation left a detached city of Hradec Králové with less than $4 \mathrm{~km}^{2}$ and 200 populated houses within the walls and with a maximum population of 4,000 .

Further urban development of the new housing estate was significantly affected by regulation of Labe and Orlice water courses and by political separation of large and functionally significant city districts of Nový Hradec Králové, Kuklen, Pouchov, Svobodné Dvory, Slezské Předměstí and Pražské Předměstí. Since 1850 , these districts were developing independently under the influence of provincial patriotism and regardless of the general building growth of "Velký Hradec Králové" for the following 90 years.

The first major impulse of the urban development occurred on 20 June 1858 when the fort headquarters were abolished including withdrawal of the ban on construction within the fort district. Following withdrawal of the ban on construction, there were several public buildings and facilities built which conditioned further economic and cultural growth, in particular, buildings of civil and technical amenities of the city. Location of these buildings was limited by the space within the fort, which resulted in housing constructions (apartment houses) outside the fort at the expense of preserving the urban values and views of the historical city centre. Existence of the fort including its protective zone affected the railway corridor construction (in 1857, Pardubice-Liberec line). Connection to the railway resulted in significant economic growth even despite its location outside the centre of Hradec Králové which thus obtained free space for conceptual urban development on the right bank of the Labe River. Industrial facilities were situated in a similar manner, i.e. beyond the fort protective zone boundaries. This limitation created space for implementation of sophisticated urban concepts [1].

\section{Fort cancellation and conversion}

On 18 July 1884, the Emperor rendered decision ordering cancelation of the Hradec Králové fort with partial demolition of the walls and with Hradec Králové 
to be no longer considered a fortified city. Demolition of part of the fortification started in September 1884 when the total costs of removing mature walls and fortress banks became evident. After several years of arguing with the Minister of War over transfer of lands, the city obtained the lands, being aware of the further investments. While arguing about the transfer of lands, the city posted an international contest for the first city regulation plan (see Figure 1).

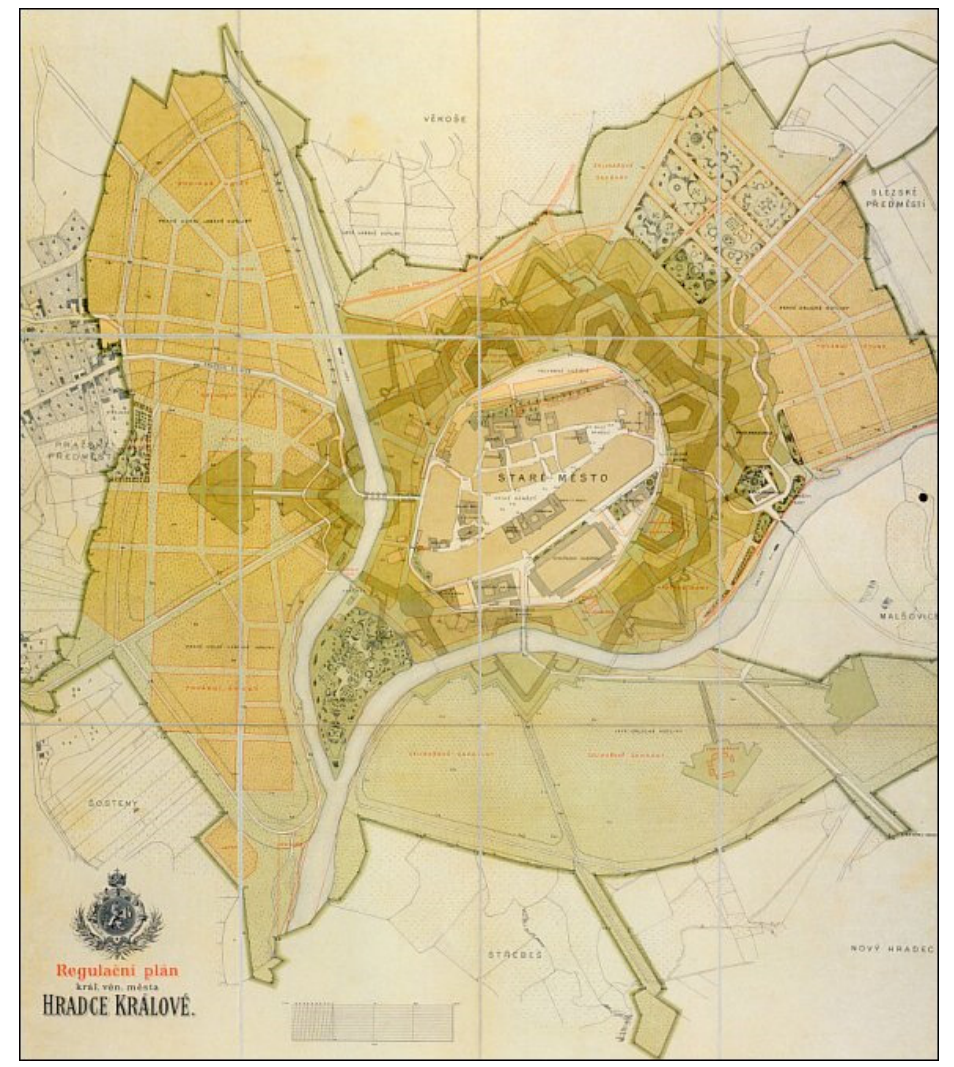

Figure 1: Regulation plan of Hradec Králové (source: http://www.hiu.cas.cz).

\section{Redevelopment Law}

This was a supportive mechanism that enhanced the construction activity on lands of the former fortress. The state attempted to stipulate the building development in the territory of cisleithan part of monarchy back in 1880s by releasing the law of temporary tax exemption of new, redeveloped or annexed houses. Validity of exemption from tax on rental, class house tax and state charges was limited to a period of 12 years as from the building approval. In the 1890s, when the Redevelopment Law validity was to expire, the respective administrative 
authorities decided not to extend it. This law significantly affected the state budget income. In order to moderate impacts of the Redevelopment Law, it was decided to preserve special statutory regulations with limited local operation in form of tax exemptions. This concerned selected cities of the monarchy (Brno, Graz, Kraków, Ljubljana, Lviv, Olomouc, Opava and Prague), the development of which had to be important for the government. Such primary approach to redevelopment was expanded to three regional cities (Hradec Králové, Przemyśl and Bielsko). Each of these cities applied its own modernization strategy.

The imperial law for Hradec Králové was signed on 8 February 1897. Pursuant to this law, new and rebuilt houses within the fortress zone were exempted from taxation for a period of 18 years on the provision they were completed within 10 years as of entry of this law into force.

\section{Hradec Králové architectural focus on functional use}

The Hradec Králové architecture of the first three decades of the twentieth century significantly influenced the city representation throughout the country in this period of time. It adequately supplemented the cultural environment of Hradec Králové which managed to maintain and found new institutions of various kind and cultural organizations. The individual architectural designs often required creation of a permanent functional background for these entities.

The city gradually worked on projects which supported activities of museums, libraries galleries or theatres. They also contributed to the fact that it became the promoter, host or participator of exhibitions, conventions and congresses. Courses of lectures were also very frequent in the city. Besides the historical and industrial museums, it was promoted by the district cultural board, Trade Promotion Institute, established in course of the World War I, or the Glassmaking Institute that was founded here in the 1920s. In addition, the city was a centre of various linguistic clubs and sports and physical training units. A major part of cultural life in Hradec Králové was represented by local schools and educational institutes.

The city space was not formed in an uncontrolled or chaotic manner. This was all led by the effort to form urban composition in a complex manner with respect to surrounding, harmonize the new architectural works with already existing buildings and create and follow such models and designs which would contribute to better functioning of the social and cultural complex.

In 1925, architect Josef Gočár was assigned to generate the regulation plan for the city of Hradec Králové. The submitted regulation plan respected the fortress ground plan, while designing radial and circular traffic system. The traffic system consists of six radial roads coming out of the "inner circuit" (copying the shape of the old city) which interconnect it with the outer circuit. These basic and limiting concepts were complemented by the designed public green system in form of green zones. The old city was embraced by an integrated green zone with five green bands radially coming out it, creating space for pedestrians and bicyclists, including connection to public parks, orchards and gardens. Situation of the public green areas is the basic parting element between the city centre and residential zone. It also forms a natural hygienic and social barrier from noise 
and air pollution including light pollution. It forms natural shielding elements in summer, which avoids excessive heating of street parterres.

Construction of Hradec Králové as such was completed by the end of the 1930s. The new western city district became a unique conceptual work and assumed the role of a new city trading market thanks to traffic connection not only to the road, but also to the railway transport. The old historical city at hillock was protected against modern interventions at the expense of weakening the central functions, but it still preserved its key position not only within the centre of Hradec Králové, but also in relation to the bi-centric agglomeration.

\section{Present zoning in Hradec Králové}

The present zoning in the territory of Hradec Králové is inspired by urban concept of ÚPVÚC (zoning of higher territorial unit) Hradec and Pardubice Regional Residential Agglomeration. This document was the base for the first City Zoning Plan that became effective in 2000. Since 2002, change of zoning plan of a subterritory is being approved on an annual basis which includes not only layout modifications, but also changes in functional utilization and modification of directives. Comparing the urban approach to creation of the first regulation plans to the present zoning documentation, we find apparent fragmentation of the urban concept. There are zoning studies and regulation plans generated for several key locations as one of the significant sustainable urban development tools.

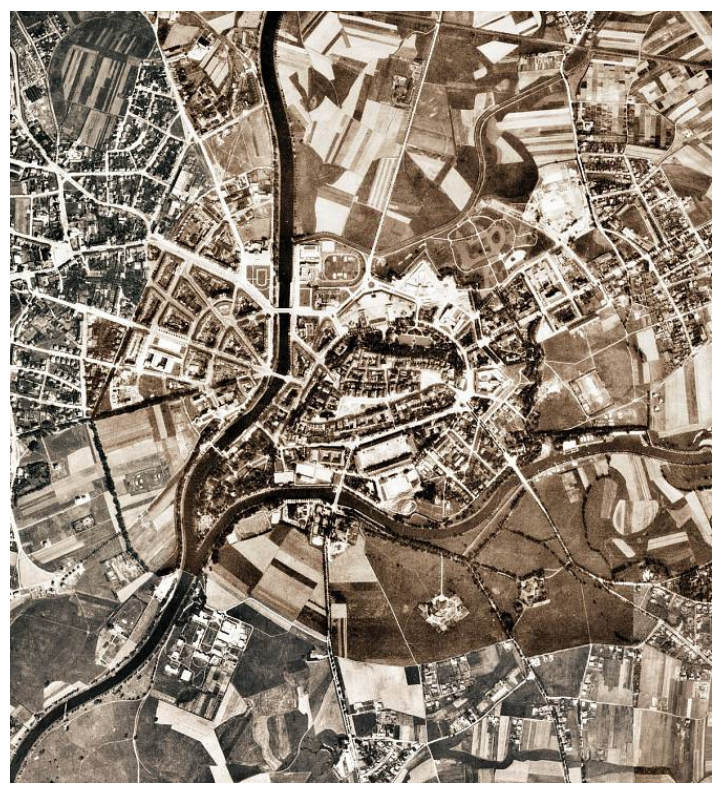

Figure 2: Aerial photo of the city of Hradec Králové of 1937 (source: http://hradecky.denik.cz). 


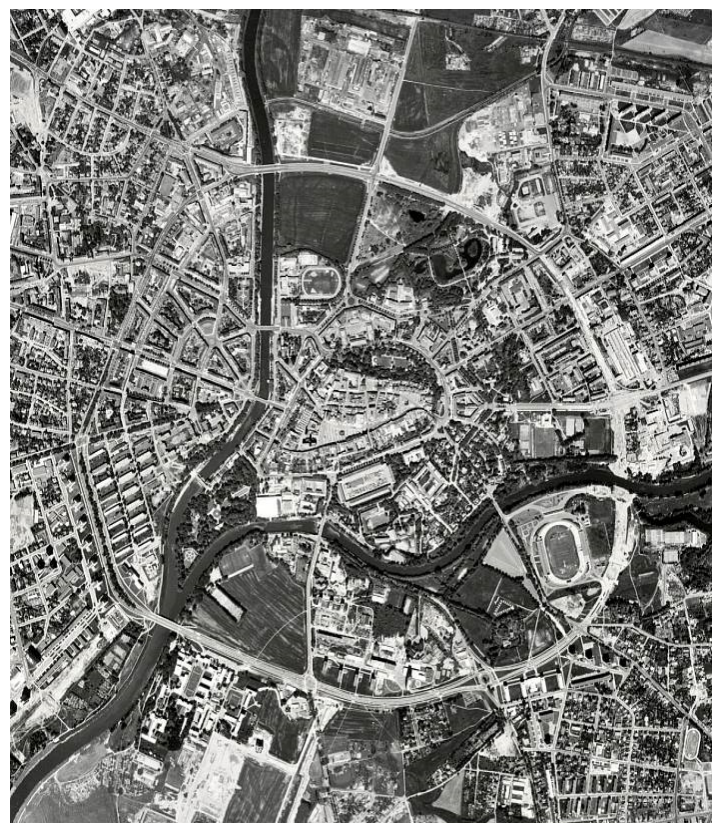

Figure 3: Aerial photo of the city of Hradec Králové of 1977 (source: http://hradecky.denik.cz).

Works on the new zoning plan, the design of which deepens Josef Gočár's ideas, started in 2009. It offers new streets, quarters, but also tram transportation, international airport and transformation of several brownfields. The urban concept has been designed in two alternatives. Besides layout of the city centre and its suburbs, it also deals with development of the peripheral quarters including development of trolleybus transportation, dwelling and industry. The city population is expected to increase to more than 110,000 till 2050 , whereas the current population is about 92,000 .

The new zoning plan intends to modulate traffic in the historical centre and to create the "third circuit of Hradec Králové". The new zoning plan also respects the natural conditions of the city with its numerous parks and green areas, directly entering the city with the Labe and Orlice Rivers, creating space for establishing recreation locations directly in the city centre. One of the main elements includes the city boulevards. New boulevards are designed after the fashion of Josef Gočár, always with an exposed dominating feature. One of them will be the newly established radial road, extending the Gočár avenue, a newly established radial road for the development area of Temešvár and Červený Dvůr with connection to the south conjunction road with connection to Pardubice and a new airport boulevard with a radial road leading to the airport area.

The traffic infrastructure significantly affects the current railway traffic in terms of the transport connection between the capital city of the Czech Republic Prague and Hradec Králové. This line should be redirected to the Pardubice line 


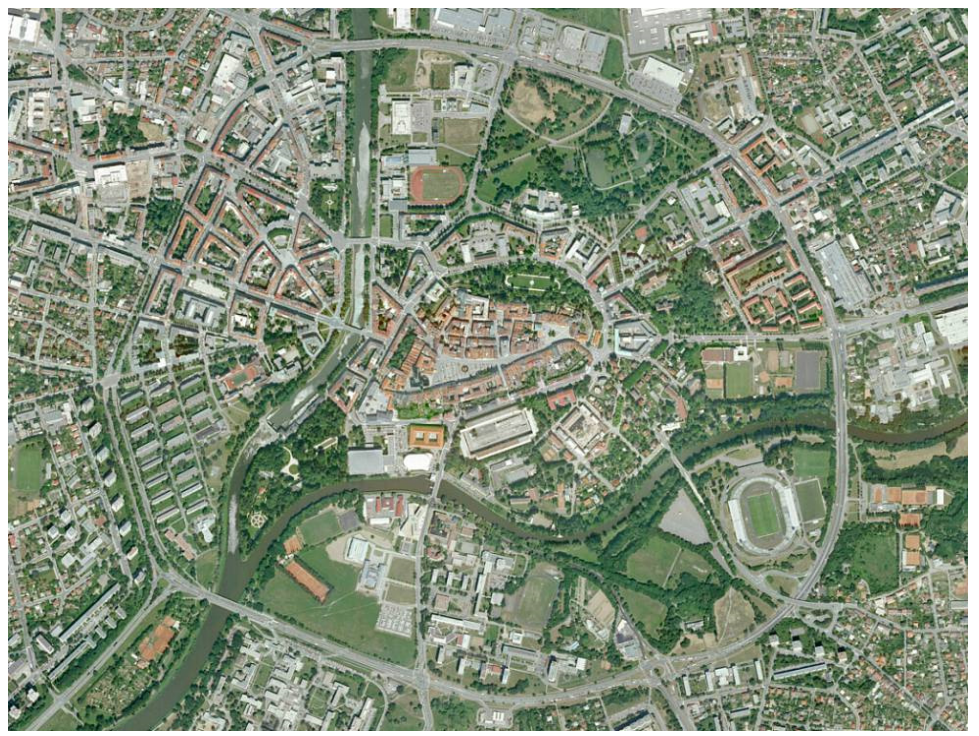

Figure 4: Aerial photo of the city of Hradec Králové of 2008 (source: http://hradecky.denik.cz).

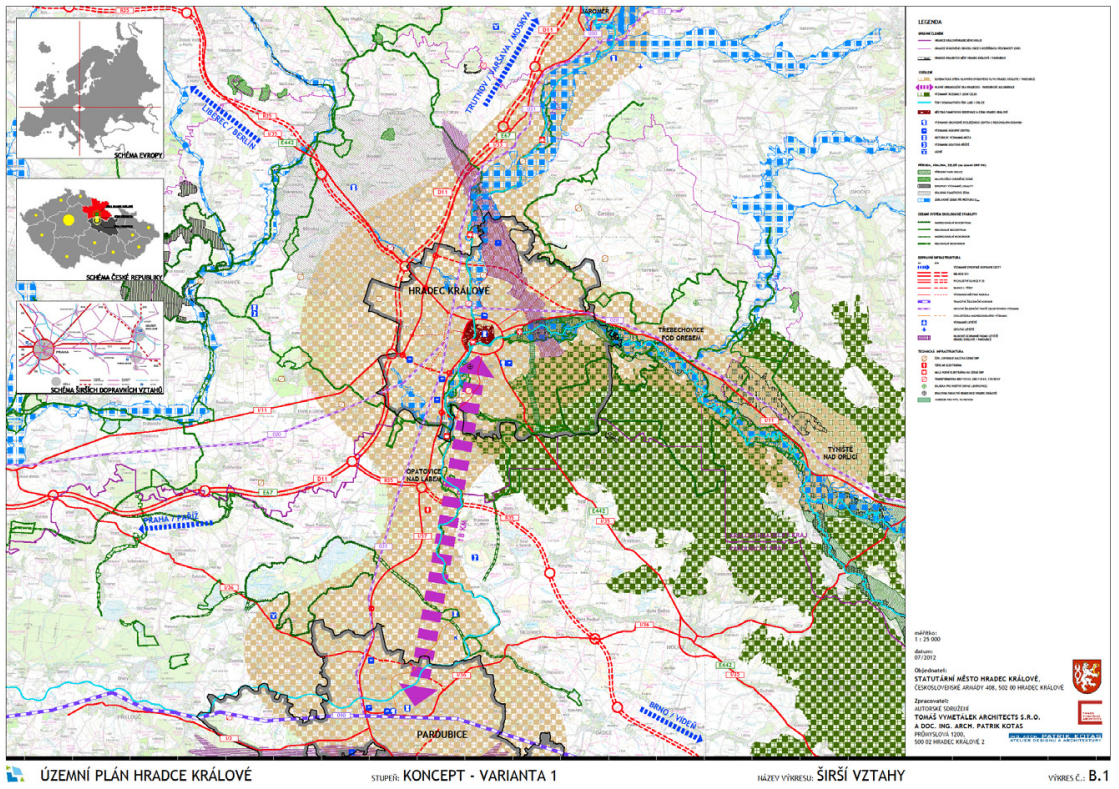

Figure 5: Wider relations plan of the zoning concept - Alternative 1 (source: http://www.hradeckralove.org). 
in order to create better functional interconnection of the new development areas for both industry and dwelling. This traffic design underlines the concept of tramtrain hybrid vehicles which can drive on the existing railway lines, as well as on the newly established lines directly in streets as trams. However, this does not mean that tram transport will be massively brought into the centre of Hradec, the system is based on utilizing the present lines, entering the development areas in form of a tram.

One of the city polycentric development tools is assurance of high-quality availability of civil infrastructure in the individual parts of the city. The polycentric system comprises city centre, city boulevards, city sub-centre and suburban sub-centres. This system includes different layouts including directives which should ensure the urban concept sustainability and strengthening of economic activity of the city.

The urban development specification is based on the development concept that is given by utilization of areas within the built-up area and "greenfield" areas. Modelling of the need of built-up areas for dwelling was conducted with two zoning plan alternatives which have different specifications of areas designated for building and areas designated for redevelopment.

Alternative A considers construction of new apartments in stabilized areas and partly in redevelopment areas with most of the apartments in "greenfields".

Alternative B considers maximum utilization of redevelopment areas and stabilized territories.

Alternative A realistically assumes that $40 \%$ of new apartments will be built in the stabilized territory and in redevelopment areas, i.e. $60 \%$ remains for the areas designated for construction.

An optimistic assumption was chosen for alternative B. Most apartments were supposed to be situated in the stabilized territory with only $20 \%$ of apartments to be created in redevelopment areas, areas designated for construction.

Both of these alternatives need to consider the economic aspect of availability mainly of the redevelopment areas. High input costs can be controlled in connection with other major investments in production and civil amenities in order to ensure polyfunctional interconnection, and thus moderation of the economic burden. With respect to the character of Hradec Králové and assumed method of development, the average size of land for a family house was estimated at 1,000 $\mathrm{m}^{2}$ in both alternatives. Regarding the assumed price of such land, the size of the land is rather assumed to be $800 \mathrm{~m}^{2}$. These numbers need to be increased by $20 \%$ for roads, public areas, green areas and technical infrastructure. With respect to reality of utilization of the redevelopment areas for dwelling purposes, the realistic need of areas designated for housing construction in Hradec Králové for the period of $2012-2017$ has been estimated at $174-360$ ha. The total city extent is currently 10,596 ha.

\section{Conclusion}

The city of Hradec Králové used the opportunities it had thanks to ownership of adjacent land which it donated to the state authorities and establishments free 
of charge. These mainly include schools, hospitals, courts, barracks, airport and state residential houses, it donated selected buildings (sports clubs, state railways headquarters) for a symbolic fee or contributed financially. Direct conceptual and operative management of construction was performed by the city technical office. Urbanism in Hradec Králové was so much unattainable since establishment of the first republic, which yielded in reputation of a global scale.

A major part of Hradec Králové (the historical centre) has been protected since 1987 as a protected municipal reserve and protective zone of municipal protected area, and since 1990 as a municipal protected zone and protective zone of municipal protected area. The zoning plan draft deals with the layout concept, broken down to 7 types. One of them is the "slow-growing" structure of the historical centre. Such structure is limited by the declared municipal protected reserve of Hradec Králové. Spatial regulation of this territory is the subject of the state monument preservation and is governed by conditions of the declared municipal protected reserve. This is the reason why maximum number of storeys has not been determined for this type of development structure. The structure features slow-growing ground plan of a gothic city, the public areas respond to the original historical road network, all in mutual hierarchic relations. The new urban concept of "circuit III" was determined based on these territorial values, enabling interconnection of Hradec Králové, its polycentric system along urban axes and urban or suburban sub-centres.

\section{Acknowledgement}

The work was supported by the Student Grant Competition VSB-TUO. Project registration number is SP2016/46.

\section{References}

[1] Královéhradecko - historický sborník pro poučenou veřejnost, Edition: 2, 2005, page 11-14, ISBN 80-85031-51-5, Czech Republic - State District Archive of Hradec Králové.

[2] Královéhradecko - historický sborník pro poučenou veřejnost, Edition:7, 2010, page 153, ISBN 978-80-85031-86-7, Czech Republic - State District Archive of Hradec Králové.

[3] Benešova, M. Toman, F. Jakl, J. Salón republiky, Moderní architektura Hradce Králové. Hradec Kralove: Garamon, 2000. page 71

[4] Vymetálek T. Architects s. r. o, Zoning Plan of Hradec Králové - concept, 07/2012, http://www.hradeckralove.org/urad/novy-uzemni-plan-hradcekralove 